\title{
Policy-Making in Nonformal Education
}

\author{
Elih Sudia Permana, Yanti Shantini \\ Department of Non Formal Education \\ Faculty of Education \\ Universitas Pendidikan Indonesia \\ Bandung, Indonesia \\ elsud@upi.edu
}

\begin{abstract}
In nonformal education, community participation is the key point of sustainable program, which formed to the future development. The process of policy-making in nonformal education should involve the community, while aspirations of the stakeholder may influence the policy-making. So that, it needs many steps to consider for a policy-maker based on the regulation and participation of community. The research is aimed to describe how government organized the policy-making process in nonformal education that involved different parties. This research using qualitative method that involving 3 stakeholders in Bandung City Region as subjects with documents' analysis, interview and focus group discussion as technic for data gathering. The result from the studies is the policy-making process in Nonformal Education are should design based on the need and condition of community. Second step is agreement with stakeholder to make an agreement about the way for socialization, finances, etc. The third is the public test, this way to know how far the community needs that policy. And last step is socialization, to make the community know about the policy.
\end{abstract}

\section{Keywords-Policymaking; Nonformal Education}

\section{INTRODUCTION}

The rule that made by policy-maker to decrease community problems. Behavior pattern in community which is not accordance with regulation will get punishment to organize the community living. This action is taken by community creating good living and brings the safety from criminal action.

A nation advancement is influenced by human resources, which build community character. It needs people who have idea and authorized to organize and utilize existing resources, in both of nature and human resources. The authority stakeholders are persons that have been trusted by community for contributing in each their expertise field to increase the prosperity.

The empiric facts showed that people should give idea and physical contribution to government who responsible in empowering community. The government should cover the aspirations from community and stakeholder the selected aspiration to improve the quality life of community. [1]

The given aspiration will be reviewed again and will be synchronized with current regulation and if necessary will be used as policy. Policy-making is one of the actions for advancing a nation. Policy made based on issues, which existing in community, and it is not accordance to current regulation. Policy take actions as the alternative of solving present problems/issues.
Policy is the way to combine community values and law regulation. Education policy as a main part in increasing Human Development Index (HDI) in Indonesia where social institutions in community always evolve and empowered to give professional and good education service.

Implementation of non formal education which involves people makes the policy based on community needs. The community needs generalized and reviewed according to the condition of people, and it can be implement. It means people who had a role to arrange policies on the non formal education are the people who have the authority and people who understand education non formal. It is focused on the parties who have authority in preparing policies on the non formal education and steps done to arrange non formal/informal policy.

According to [2] there are two characteristic of public policy. First public policy as something which is easy to understand because the interpretation of it are things that have been done by to achieve the aim of national. Second public policy is something which easily measured because of its size clear namely the extent to which the progress of the ideals that have been taken. According to Iskandar, legislation is a form of public policy concrete. Public policy as legislation can be described as goods public

[3] Expressing there are three phases of technically in preparing policy namely policy formulation, policy implementation, and policy evaluation. Policy formulation is stages of policy formulation, early steps in formulating a policy. This phase will determine the success of a policy therefore stage policy formulation this must be implemented by many considerations.

While policy implementation is stage of policy. It means in this stage policies that formulated have shaped the academic paper and will implemented, And phase of policy evaluation is stage policy evaluation, after policy implemented and walk some time we need to hold evaluating whether needed repair to the policy or the removal and replaced with the policy which new.

\section{METHOD}

This research use descriptive study to stakeholders in the city of Bandung which is local government staff, expert judgement UPI, and manager of CLC. Data collection techniques used in this research study consisting of documentation, the study of literature, the study primary data, interview. Sample of this research focused on parties who participated in preparing policy 
in the City of Bandung. Data and information obtained in the form of qualitative information and open interview. All the respondent gathering to have focus group discussion and the result of discussion are validate through interview for gaining reliable data.

\section{RESULT AND DISCUSSION}

Policy in Bandung city made the need and condition of community. Local government staff said that "The policies set out in the service of non-formal education is still centered on policy rules set by the central government. The local government still has a function to promote the policy and still has not made a breakthrough in strengthening the policy achievements of the center. This is primarily related to the budget is still very limited".

Based on the interview with second respondent with expert from UPI, the most important thing is to develop policy, the policy not overlap existing rules and in accordance with community needs. In other words there must be harmony between one policies by other policy shall be consistent with regional autonomy.

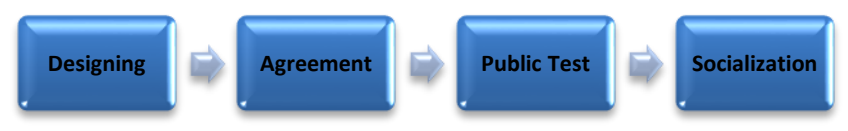

Fig. 1. Stage The Preparation Of Policy In The Field

First is stage design, in this phase authors policy must weigh three things that is long-term development plan (RPJP), medium-term development design (RPJM), strategic plan (RENSTRA). All these three things are sensitive and related to the future measures which would designed because with the new policy so it would effect on the to be used in implement this policy. The Second is phase of agreement, this stage is part of the team building blocks to consider of the aspect of juridical, aspects philosophical and aspects sociological. Aspects juridical is the phase that which the policy in terms of law or science. Philosophical aspect is a description on policy based on what is ideals in accordance with Pancasila. While the sociological itself is a foundation related to things in a society as development, the needs and people characteristics targeted.

Third was public test stage, whereby on this stage after it was agreed the policy to this is going to applied to some targets next objective to see whether the policy could be implemented or not. At this stage, the community can contribute inform ongoing every opportunity that discuss the policy. The Fourth is phase of socialization, in this phase policy has become the academic paper ready for applicate in related persons. This stage is needed to give understanding thoroughly and that there are in common perception for a policy. This phase shows preparation mentally target policy by the existence of new policies made.

Regulation number 12 year 2011 explained the five of to develop policy. The first was planning stages, where is the building blocks the policy review the conditions on the ground associated with existing issues. In this planning phase, observers have to be seen how readiness components to make policy and how accommodation for implementation of policy.

Second stage in the preparation of policy is to formulate policies itself. After assessing the fact in the field as well as the rules are supposed to be obeyed the policy to have to be developed in a mature manner because policy was based on research is not only based on suspects while.

The third stage is the public. In this phase the community can serve in the preparation of policy itself because to be affected are although it is not thoroughly. When the policy started in themselves and found things that does not conform or even difficult to be implemented may be put forward to the producer this socialization or aspirations can be delivered when held event related to the policy.

Fourth stage. In this phase policy have entered the domain of law to coming will be conducted plenary meeting to discuss the coming the possibility of about the policy after reached an agreement and is in line with various aspects of the policy is to agreed and will shaped manuscript academic ready to enter next stage.

The final stage is socialization, it is not less important other step. In this stage is an important part of model for the socialization that did not concept and impalements policy would not be consistent with the objectives of the policy itself, so the stage is an essential part in preparing policy. The objective is to components related having an understanding to somebody goal at the purpose of these policies itself. The fact in the field showed although the stage of different suits the concept that is in the constitution but components contained remained the same and not much happened shift. To arrange policy adhere to these part.

\section{CONCLUSION}

The conclusion of this research study is: First, many role of policy-making in Nonformal Education. The important in policy-making, the policy based on community needed. The first step to make a policy is designing the policy based on regulation and the problem in community. Second step is agreement from stakeholder. This role to make agreement reached about the way for socialization, finances, and etc. The third is public test, this way to know how far the community need that policy. And last step is socialization, to make the community know about the policy.

\section{REFERENCES}

[1] Departement of Law and Human Rights. (2011). Government Regulation Number 12 In 2011 About The Establishment of Regulatory Law. Jakarta; Department Of Law and Human Rights.

[2] Nugroho Riant. (2007). Analisis Kebijakan. Jakarta: PT. Gramedia Jakarta.

[3] Widodo, Joko. (2007). Analisa Kebijakan Publik. Malang:Bayu Media Publishing.

[4] Van den Hove, S., \& van den Hove, S. (2000). Participatory Approaches to Environmental Policy-making: The European Commission Climate Policy Process as a Case Study. Ecological Economics, 33(3), 457-472 